\title{
Physiological responses to environmental variation in intertidal red algae: does thallus morphology matter?
}

\author{
Steven R. Dudgeon ${ }^{1,2}$, Janet E. Kübler ${ }^{1,3}{ }^{\text {, Robert L. } \text { Vadas }^{1}{ }^{1} \text { Ian R. Davison }}{ }^{1}$ \\ ${ }^{1}$ Department of Plant Biology and Center for Marine Studies, University of Maine, Orono, Maine 04469, USA \\ ${ }^{2}$ Osborn Memorial Laboratories, Department of Biology, Yale University, New Haven, Connecticut 06511, USA \\ ${ }^{3}$ Department of Biological Sciences, Dundee University, Dundee, Scotland DD1 4HN, UK
}

\begin{abstract}
Morphological variation within and among many species of algae show correlated life history traits. The trade-offs of life history traits among different morphs are presumed to be determined by morphology. Form-function hypotheses also predict that algae of different morphological groups exhibit different tolerances to physiological stress, whereas algae within a morphological group respond similarly to stress. We tested this hypothesis by comparing photosynthetic and respiratory responses to variation in season, light, temperature, desiccation and freezing among the morphologically similar fronds of Chondrus crispus and Mastocarpus stellatus and the alternate stage crust of M. stellatus, Physiological differences between fronds of the 2 species and crusts and fronds were consistent with their patterns of distribution and abundance in the intertidal zone. However, there was no clear relationship between algal morphology and physiological response to environmental variation. These results suggest that among macroalgae the correlation between life history traits and morphology is not always causal. Rather, the link between life history traits and morphology is constrained by the extent to which physiological characteristics codetermine these features.
\end{abstract}

KEY WORDS: Chondrus - Desiccation - Mastocarpus - Morphology - Photosynthesis - Red algae · Respiration - Temperature

\section{INTRODUCTION}

Biologists studying plant, animal and fungal systems have independently observed correlations between life history traits and morphology. In each case the evidence indicates that morphological variation has ecological significance. Tests of the form-function hypothesis on macroalgae (Littler \& Littler 1980) have focused on the trade-offs of life history traits among different morphs, and have provided hypotheses about the adaptive characteristics, as well as the constraints, of each morph (Littler \& Littler 1980, Lubchenco \& Cubit 1980, Slocum 1980, Dethier 1981, Littler \& Arnold 1982, Steneck \& Watling 1982, Hannach \& Santelices 1985, Hanisak et al, 1988, Zupan \& West 1990, Steneck \& Dethier 1994). For example, rates of biomass-specific light saturated photosynthesis are lower in morphologically complex macroalgae (e.g. Fucus) than in simpler forms, (e.g. Ulva) presumably because of the decrease in surface area per unit biomass available for light harvesting and nutrient uptake, and the increase in non-photosynthetic structural tissue. The form-function hypothesis has been extensively applied to many areas of seaweed biology including studies of herbivory, nutrient uptake, and productivity. It is implicit in such studies that correlations between life history traits and morphology are causal.

The form-function hypothesis also predicts that algae of different morphological groups exhibit different tolerances to physiological stress (e.g. desiccation, freezing, thermal stress), whereas algae within a morphological group respond similarly to stress. However, this hypothesis has not been as widely tested as those relating to productivity, nutrient uptake or herbivory. The demonstration that a saccate morphology reduces desiccation (Oates 1985, 1986) is presently the best evi- 
dence of morphological characteristics affecting physiological tolerances of macroalgae. Evidence from other studies indicates that physiological differences may, or may not, exist among morphologically similar thalli (Hannach \& Santelices 1985, Davison et al. 1989, Britting \& Chapman 1993). Zupan \& West (1990) observed differences in photosynthetic responses to light and temperature between heteromorphic phases of Mastocarpus papillatus. In this study, we compared the physiological responses of fronds of Chondrus crispus and Mastocarpus stellatus, and the alternate crustose stage of the latter species, to several important variables (seasonal variation of light use, temperature, desiccation and freezing) that occur in the marine intertidal zone. We addressed the questions of whether (1) the physiological responses to environmental variation are determined by thallus morphology, and (2) observed physiological differences are consistent with predictions based on patterns of distribution and abundance.

The red macroalgae Chondrus crispus and Mastocarpus stellatus dominate the lower intertidal zone ( $\leq 0.75 \mathrm{~m}$ above mean low water, MLW) of many rocky seashores in Maine, USA, and range biogeographically from Long Island Sound, New York, USA, to southern Newfoundland, Canada, in the western, and Morocco to northern Scandinavia in the eastern, north Atlantic Ocean (Guiry \& West 1983, Lüning 1990). Although several studies have examined the ecological processes determining the distribution and abundance of these species in the intertidal zone (Mathieson \& Burns 1971, 1975, Burns \& Mathieson 1972, Lubchenco 1980, Green 1983, Dudgeon et al. 1989, 1990, Dudgeon \& Johnson 1992), none of these studies included the crustose tetrasporophytic stage $(=$ Petrocelis; West et al. 1977, Guiry \& West 1983) of M. stellatus, either because the research was conducted prior to the discovery of a crustose tetrasporophyte in the life history of the species, or because the crusts were not recognized in the study areas. In fact, very little is known about the ecology or physiology of the crustose tetrasporophytic stage of most species in the genus Mastocarpus; a notable exception being $M$. papillatus (Paine et al. 1979, Slocum 1980, Littler \& Arnold 1982, Zupan \& West 1990, Dethier 1994). Our understanding of the ecological and evolutionary significance of heteromorphic life histories among macroalgae in general, and the ecology of the 'Chondrus-Mastocarpus' mixed assemblage of low intertidal rocky shores in the north Atlantic Ocean in particular, is enhanced by comparative physiological and ecological studies of M. stellatus.

We have observed that the crustose tetrasporophyte (Petrocelis phase) of Mastocarpus stellatus (hereafter 'crust') is common on rocky intertidal shores of the Gulf of Maine, and that its distribution within the intertidal zone differs from that of erect thalli (hereafter 'fronds') of this species. Crusts of $M$. stellatus occupy most of the substrate not covered by holdfasts of Chondrus crispus below $0.25 \mathrm{~m}$ MLW where an almost pure canopy of the latter predominates (Dudgeon 1992). The abundance of crusts of $M$. stellatus is reduced at higher elevations on the shore ( $>0.25$ to $0.75 \mathrm{~m}$ ) where fronds of $C$. crispus and $M$. stellatus form an evenly mixed stand. C. crispus and crusts of $M$. stellatus occur infrequently in the uppermost level of the lower intertidal zone ( $>0.75$ to $1.00 \mathrm{~m}$ MLW) that is dominated by fronds of $M$. stellatus and fucoid algae. Previous studies indicated that the photosynthetic metabolism of C. crispus is more inhibited by desiccation and freezing than that of fronds of $M$. stellatus, presumably limiting the growth rate and abundance of the former species higher on the shore (Mathieson \& Burns 1971, Green 1983, Davison et al. 1989, Dudgeon et al. 1989, 1990). In general, a positive correlation exists between vertical zonation patterns of intertidal macroalgae and tolerance to stresses, such as freezing and desiccation (i.e. low shore species exhibit low tolerance; Zaneveld 1969, Connell 1972, Mathieson \& Burns 1971, Smith \& Berry 1986, Davison et al. 1989). On the basis of different distributions of frondose and crustose phases of $M$. stellatus, we predicted that crusts of $M$. stellatus would be less tolerant of physiological stress than are fronds.

The 2 isomorphic phases of Chondrus crispus also may exhibit different distributions with gametophytes dominating intertidally and tetrasporophytes subtidally (Mathieson \& Burns 1975). The intertidal population at our study site, Chamberlain, Maine, was consistent with this pattern, being comprised of $>80 \%$ gametophytic fronds (Kübler 1992). However, exceptions to this pattern among populations of $C$. crispus occur (Prince \& Kingsbury 1973). Physiological differences related to ploidy level have been observed in some isomorphic red algae (Hannach \& Santelices 1985), but not in others (Britting \& Chapman 1993). Previous studies of isomorphic phases of $C$. crispus indicate that gametophytes and tetrasporophytes exhibit similar physiological responses (Mathieson \& Norall 1975, Chopin \& Floch 1992), and for this reason we did not distinguish between the 2 phases in our study.

In this paper we present evidence that the physiological differences between the heteromorphic stages of Mastocarpus stellatus are consistent with the hypothesis that their respective upper distributional limits in the intertidal zone are determined by physical factors. Overall, the physiological responses to environmental variation observed among fronds of Chondrus crispus and $M$. stellatus and crusts of the latter species indicate that as much variation in physiological responses exists within a morphological group as among morphological groups, thus there was no clear association between physiology and algal morphology. 


\section{MATERIALS AND METHODS}

Collection and culture conditions. Fronds of Chondrus crispus and Mastocarpus stellatus were collected from the shore at Long Cove Point, Chamberlain, Maine $\left(43^{\circ} 54^{\prime} \mathrm{N}, 69^{\circ} 28^{\prime} \mathrm{W}\right)$ at approximately 0.25 to $0.35 \mathrm{~m}$ above MLW in November 1989 (photosynthesis-photon flux density, PI, measurements) and May through July 1990 (photosynthesis-photon flux density, and all other experiments). Crusts of $M$. stellatus were collected at the same site by fracturing the rock with a hammer and chisel. Algae were transported to the laboratory in seawater, cleaned of visible epibionts and placed in plexiglass aquaria containing 61 of aerated, filtered and enriched seawater (PES; Provasoli 1968). Media were changed twice weekly. Cultures were maintained at 70 to $80 \mu \mathrm{mol}$ photons $\mathrm{m}^{-2} \mathrm{~s}^{-1}$ in a $16: 8 \mathrm{~h}$ light:dark cycle at $5^{\circ} \mathrm{C}$ (for November collections and thalli for freezing experiments) or $15^{\circ} \mathrm{C}$ (for all other experiments). Light-use characteristics were measured within 1 to $2 \mathrm{~d}$ of collection. All other experiments were initiated within $7 \mathrm{~d}$ of collection.

Photosynthetic and respiratory measurements. Photosynthesis and respiration were measured in a Clark-type oxygen electrode (Rank Bros., Botisham, $\mathrm{UK})$ at 0 and $600 \mu \mathrm{mol}$ photons $\mathrm{m}^{-2} \mathrm{~s}^{-1}$. Apices from frondose Chondrus crispus and Mastocarpus stellatus thalli ( 0.5 to $1.0 \mathrm{~cm}$ in length), or thin sections of rock with crusts of $M$. stellatus $(\sim 1 \mathrm{~cm}$ in diameter, obtained by slicing the rock in the plane parallel to the crust surface with diagonal cutters), were held at $90^{\circ}$ to the light source with nylon mesh, to ensure uniform illumination in the electrode chamber, in $5 \mathrm{ml}$ of milliporefiltered $(0.45 \mu \mathrm{m})$ seawater, and photosynthesis and respiration were measured as described by Kuebler et al. (1991). Apices and crust sections were cut $24 \mathrm{~h}$ prior to use in experiments to allow for wound healing (Bidwell \& McLachlan 1985). Photosynthetic rates of crusts were corrected for (1) volumetric displacement of seawater in the electrode chamber, and (2) oxygen flux due to the rock, but not the alga. Oxygen flux associated with the rock was examined by comparing rates of light and dark oxygen flux of 5 crust/rock samples with rates of these same rock samples (following crust removal) alone. Crusts were removed from the rocks by slicing and scraping the surface with a razor blade, scouring with a wire brush in distilled water and ovendrying for $24 \mathrm{~h}$ at $60^{\circ} \mathrm{C}$. Rocks were rehydrated, placed in the electrode chamber and oxygen flux was measured in the absence of the alga. Oxygen flux due to the presence of the rock was negligible.

Photosynthesis-irradiance measurements. Light-use characteristics of Chondrus crispus and both morphological stages of Mastocarpus stellatus were compared between fall and spring collected thalli. Dark respira- tion and photosynthesis versus photosynthetic photon flux density (PPFD) responses were determined at $10^{\circ} \mathrm{C}$. PPFD was increased sequentially in 11 steps from 0 to $1500 \mu \mathrm{mol}$ photons $\mathrm{m}^{-2} \mathrm{~s}^{-1}$, once a stable rate of photosynthesis at a given light level had been achieved (normally within $5 \mathrm{~min}$ ). The light source, a tungsten-halide lamp in a Kodak slide projector, was attenuated with Schott neutral density filters. Lightuse characteristics were calculated as described by Gerard (1988): (1) alpha $(\alpha)$, the photosynthetic efficiency, was determined from the slope of the leastsquares linear regression curve yielding the highest correlation coefficient (r) over the range of 0 to $27 \mu \mathrm{mol}$ photons $\mathrm{m}^{-2} \mathrm{~s}^{-1}$ for each of 5 replicates, (2) $I_{\mathrm{c}}$, the compensation irradiance, was determined by solving the linear equation, $y=b x+a$, for $x$, where $y$ (net photosynthesis) $=0$, and using $\alpha$ for the slope $(b)$ and dark respiration as the $y$-intercept (a), (3) $P_{\max }$, the maximum photosynthetic rate, was estimated from the mean photosynthetic rate over the light-saturated range from 415 to $1500 \mu \mathrm{mol}$ photons $\mathrm{m}^{-2} \mathrm{~s}^{-1}$, (4) the light saturation intensity, $I_{\mathrm{k}}$, was estimated by dividing $P_{\max }$ by $\alpha$.

Thermal acclimation. To determine if Chondrus crispus and/or Mastocarpus stellatus acclimate to growth temperature, thalli were grown for 4 wk either at 5 or $15^{\circ} \mathrm{C}$. The responses of photosynthesis and respiration to temperature in thalli of both species grown at 5 and $15^{\circ} \mathrm{C}$ were tested at $5^{\circ} \mathrm{C}$ intervals from 5 to $35^{\circ} \mathrm{C}$ (except $20^{\circ} \mathrm{C}$ ). Thalli were exposed to the assay temperature only long enough to measure rates of photosynthesis and respiration (typically $10 \mathrm{~min}$ or less), and were returned to their growth temperature between measurements.

Effects of desiccation at different temperatures. To assess the effects of dehydration at different temperatures on photosynthetic metabolism of Chondrus crispus and Mastocarpus stellatus a single degree of desiccation stress $(60 \%)$ was used. This was selected because previous studies indicated that $60 \%$ desiccation at room temperature and humidity affected metabolic rates, but was not lethal to fronds of C. crispus or M. stellatus (Mathieson \& Burns 1971). Apical sections of fronds of C. crispus or M. stellatus, and sections of crusts of $M$. stellatus, were desiccated in the dark at either 20 or $30^{\circ} \mathrm{C}$ in a chamber through which a stream of $67 \%$ relative humidity (RH) air was passed. Constant humidity was maintained by passing the air stream to the incubation chamber through a $\mathrm{MgCl}_{2}$ solution (Dring \& Brown 1982). The time required to reach $60 \%$ desiccation at each temperature was determined in preliminary experiments by periodically weighing sections to determine the evaporative water loss over time. Desiccation was expressed as the percentage loss of total cellular water, which was deter- 
mined by subtracting the dry weight of oven-dried $\left(24 \mathrm{~h}\right.$ at $\left.60^{\circ} \mathrm{C}\right)$ thalli from their initial fresh weight.

Because crusts were attached to rock, it was necessary to correct for dehydration of the wet rock. Following measurements of evaporative water loss from crust/rock samples, the alga was removed as described above. The rock was rehydrated and then periodically weighed during exposure to the same desiccation and temperature regime. The rate of water loss of the rock alone was subtracted from that of the combined crust/rock value to estimate the dehydration rate of the alga alone.

The interactive effects of temperature and desiccation on photosynthesis and respiration of Chondrus crispus and Mastocarpus stellatus was determined by exposing cut sections of thalli to $67 \% \mathrm{RH}$ air at either 20 or $30^{\circ} \mathrm{C}$ until $60 \%$ desiccation. Controls were maintained in seawater at either 20 or $30^{\circ} \mathrm{C}$. Photosynthesis and respiration were measured at $15^{\circ} \mathrm{C}$ immediately after exposure and following $2,4,6$, and $24 \mathrm{~h}$ recovery in seawater at $15^{\circ} \mathrm{C}$ and a photon flux density (PPFD) of $80 \mu \mathrm{mol}$ photons $\mathrm{m}^{-2} \mathrm{~s}^{-1}$. Recovery was also measured after $8 \mathrm{~h}$ for $30^{\circ} \mathrm{C}$ exposed thalli. Photosynthetic and respiratory rates of experimental thalli are expressed as a percentage of control values.

Short-term recovery following freezing. Apices of Chondrus crispus and Mastocarpus stellatus, and thin rock sections with encrusting $M$. stellatus, collected in May 1990 and maintained at $5^{\circ} \mathrm{C}$ were frozen at $-20^{\circ} \mathrm{C}$ for $6 \mathrm{~h}$ in darkness. Algal tissue was blotted to remove surface water, and placed in a freezer in a closed plexiglass box. Controls were maintained in seawater in darkness at $5^{\circ} \mathrm{C}$. Previous experiments determined that the metabolic rates of controls exposed in humidified air $\leq 5^{\circ} \mathrm{C}$, but not frozen, were not adversely affected by a $6 \mathrm{~h}$ treatment (Davison et al. 1989, Dudgeon et al. 1989). Photosynthesis and respiration were measured at $10^{\circ} \mathrm{C}$ immediately after freezing and following $3,6,12$, and $24 \mathrm{~h}$ recovery periods in $5^{\circ} \mathrm{C}$ seawater and at a PFD of $80 \mu \mathrm{mol}$ photons $\mathrm{m}^{-2} \mathrm{~s}^{-1}$. Photosynthetic and respiratory rates of experimental thalli are expressed as a percentage of control values.

Determination of biomass, surface area and chlorophyll a (chl a). Fresh weight, projected surface area and chl a concentration were determined to (1) compare seasonal changes of chl a content relative to morphological characteristics (biomass and projected surface area), and (2) allow gas exchange rates to be expressed on the basis of either area, biomass or chl $a$. Biomass was determined by blotting each algal sample with a paper towel and weighing it on a Mettler AE 100 analytical balance. The projected surface area of an algal sample ( 1 side of an apex in the case of fronds of Chondrus crispus and Mastocarpus stellatus) was measured by weighing cut-out paper tracings of the algae.
The weight of the cut-out paper was converted to projected surface area (in $\mathrm{cm}^{2}$ ) based on a regression of weights of paper of known area. Chl a was extracted and quantified from apices and crust sections using dimethyl sulfoxide followed by methanol, as described by Duncan \& Harrison (1982).

Field growth measurements. The growth of thalli in the field was measured by embedding a small piece of rock, removed from the substrate with a hammer and chisel, bearing either holdfasts (i.e. all erect fronds removed) of Chondrus crispus or Mastocarpus stellatus, or crusts of $M$. stellatus in a $100 \times 15 \mathrm{~mm}$ plastic petri dish in marine epoxy putty (Kopper's Splash Zone Compound). Seven dishes (with 2 rocks placed as far apart as possible in each dish) for each group were secured to the shore by stainless steel screws in plastic anchors inserted into holes drilled in the rock. Transplants were placed in the low intertidal zone (ca $0.20 \mathrm{~m}$ above MLW) where both species can survive and grow rapidly. The area around transplants was cleared to eliminate density-dependent inter- and intraspecific competition between C. crispus and $M$. stellatus (Dudgeon 1992). Transplants were harvested after $1 \mathrm{yr}$ and the net growth of each species was measured. Growth of fronds of $C$. crispus and M. stellatus was determined by estimating the biomass ( $g$ dry $w t$ ) of regenerated fronds per unit area of holdfast in a transplant dish. Growth of crusts of $M$. stellatus was determined by measuring the surface area of the crust on each rock before and after the experiment. The area of holdfast or crust of each replicate was determined using the weights of paper from tracings as described above. The areal resolution for growth measures using this method was $1.73 \mathrm{~mm}^{2}$, corresponding to a radial distance of about $750 \mu \mathrm{m}$ for a roughly circular crust. The net growth of thalli was taken as a reasonable approximation of total growth because small thalli of these species growing from holdfasts are rarely dislodged by waves (Dudgeon \& Johnson 1992), transplants were placed below tide heights at which biomass losses occur due to non-hydrodynamic physical factors (Dudgeon et al. 1990), and neither species is readily consumed by herbivores present in the New England rocky intertidal zone (Lubchenco 1978, Green 1983, Dudgeon 1992).

\section{RESULTS}

\section{Seasonal photosynthesis and respiration}

Rates of light-saturated photosynthesis $\left(P_{\max }\right)$ were greater in the fall than in spring for fronds of Chondrus crispus and Mastocarpus stellatus (ANOVA, $F_{\operatorname{mog}(1,24)}=$ 10.31, p $<0.01$; Fig. 1a). No seasonal difference in $P_{\max }$ 
was observed in crusts of $M$. stellatus. Overall, $P_{\max }$ of crusts was lower than that of fronds $\left(F_{\mathrm{sp}(2,24)}=18.17\right.$, $\mathrm{p}<0.01)$. Differences in $P_{\max }$ and other light use characteristics can be attributed to differences in metabolism rather than to seasonal differences in water temperature, because measurements were made at a standard temperature $\left(10^{\circ} \mathrm{C}\right)$.

Both fronds and crusts showed similar seasonal changes in respiration exhibiting greater rates in fall than spring for both species and morphologies $\left(F_{\text {mo } \times \text { sp }(2,24)}=0.66, \mathrm{p}=0.53, F_{\text {mo(1,24) }}=10.88, \mathrm{p}<0.01\right.$; Fig. 1b). Chondrus crispus showed significantly lower rates of respiration than crusts of Mastocarpus stellatus $\left(F_{\mathrm{sp}(2,24)}=4.69, \mathrm{p}<0.02\right)$. Respiratory rate of fronds of $M$. stellatus was intermediate between the other groups.

A pronounced seasonal difference in photosynthetic efficiency $(\alpha)$ was observed in both species and morphologies $\left(F_{\text {mo }(1.24)}=93.89, \mathrm{p}<0.01\right.$; Fig. $\left.2 \mathrm{a}\right)$. Photosynthetic efficiency was 2 to 3 times greater in fall than in spring collected thalli. No difference in $\alpha$ was observed between life history phases of Mastocarpus stellatus, nor between species in either season $\left(F_{\mathrm{sp}(2,24)}=1.27\right.$, $\mathrm{p}=0.30$ ).

Seasonal variation was also observed in both $I_{\mathrm{c}}$ (the compensation PPFD, $\left.F_{\operatorname{mo}(1,24)}=5.84, \mathrm{p}=0.02\right)$ and $I_{\mathrm{k}}$ (the saturation PPFD, $F_{\operatorname{mo}(1,24)}=31.75, \mathrm{p}<0.01$ ); both were lower in fall than in spring collected thalli in both

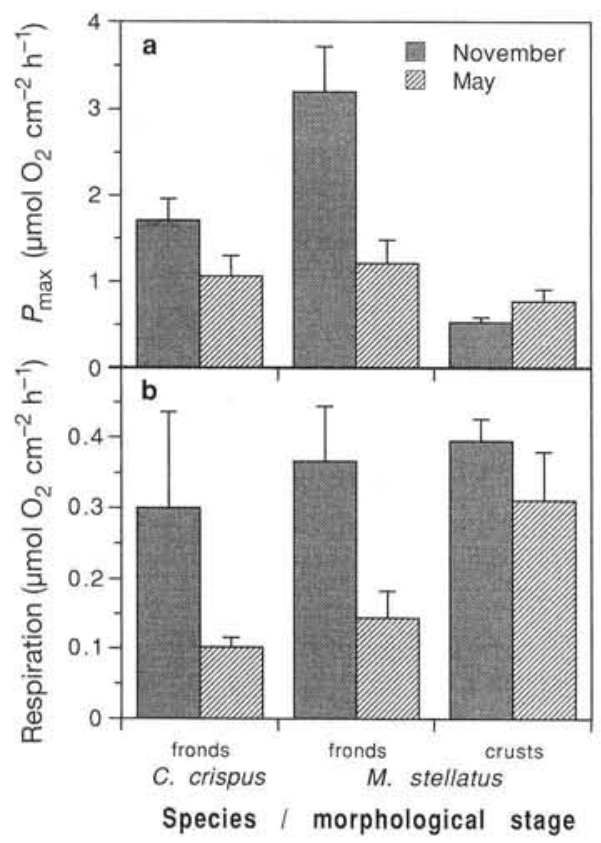

Fig. 1. Chondrus crispus and Mastocarpus stellatus. Lightsaturated rates of (a) photosynthesis and (b) dark respiration in November and May. Photosynthesis and respiration values are means $+\mathrm{SE}, \mathrm{n}=5$ species and morphologies (Fig. 2b,c). Overall, the compensation PPFD of crusts of $M$. stellatus was higher than that of fronds $\left(F_{\mathrm{sp}(1,26)}=9.42, \mathrm{p}<0.01\right.$; Fig. $\left.2 \mathrm{~b}\right)$. Crusts of $M$. stellatus required the least light to saturate photosynthesis $\left(I_{\mathrm{k}}\right)$ of the 3 groups $\left(F_{\mathrm{sp}(2,24)}=45.79\right.$, $\mathrm{p}<0.01$; Fig. 2c) and showed greater seasonal variation in $I_{\mathrm{k}}$ than fronds $\left(F_{\mathrm{sp}(1,26)}=9.16, \mathrm{p}<0.01\right)$. Fronds of $M$. stellatus required more light to saturate photosynthesis with less seasonal variation than either of the other groups.

\section{Seasonal chlorophyll, biomass and surface area}

The concentration of chl a g${ }^{-1}$ fresh wt of Chondrus crispus and crusts of Mastocarpus stellatus was greater in fall than in spring $\left(F_{\operatorname{moxp}(2,24)}=40.89, \mathrm{p}<0.01\right)$. However, no seasonal variation was observed in chlorophyll content per gram fresh wt of fronds of $M$.

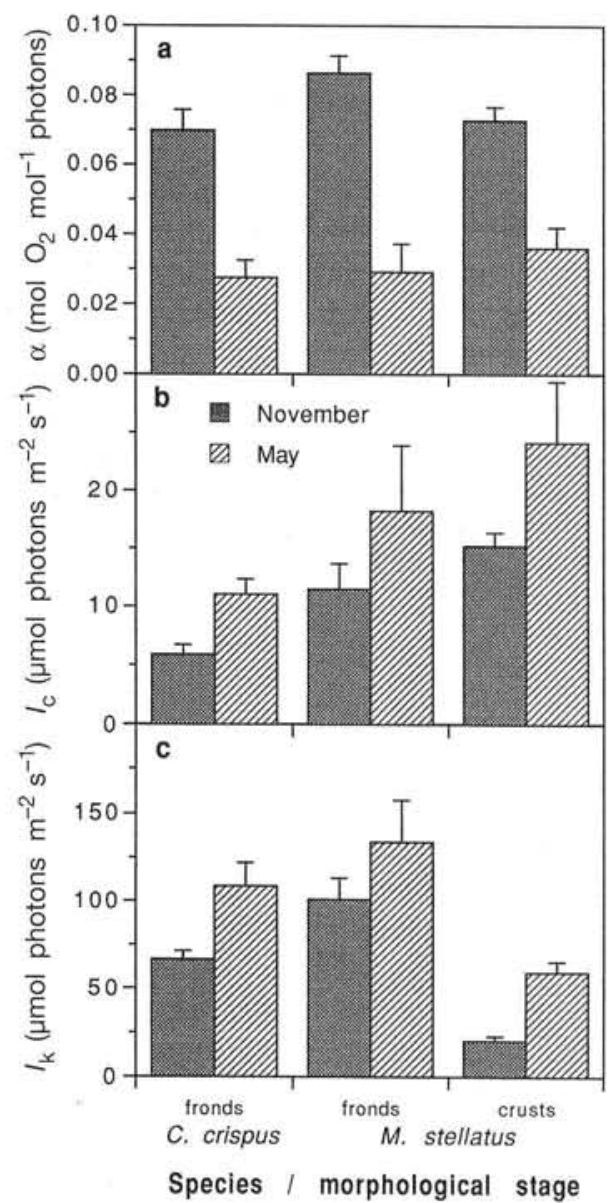

Fig. 2. Chondrus crispus and Mastocarpus stellatus. Light-use characteristics in November and May. (a) Photosynthetic efficiency $(\alpha)$ per unit thallus area; (b) compensation PPFD, $I_{c i}$ (c) saturation PPFD, $I_{k}$. Means $+\mathrm{SE}, \mathrm{n}=5$ 


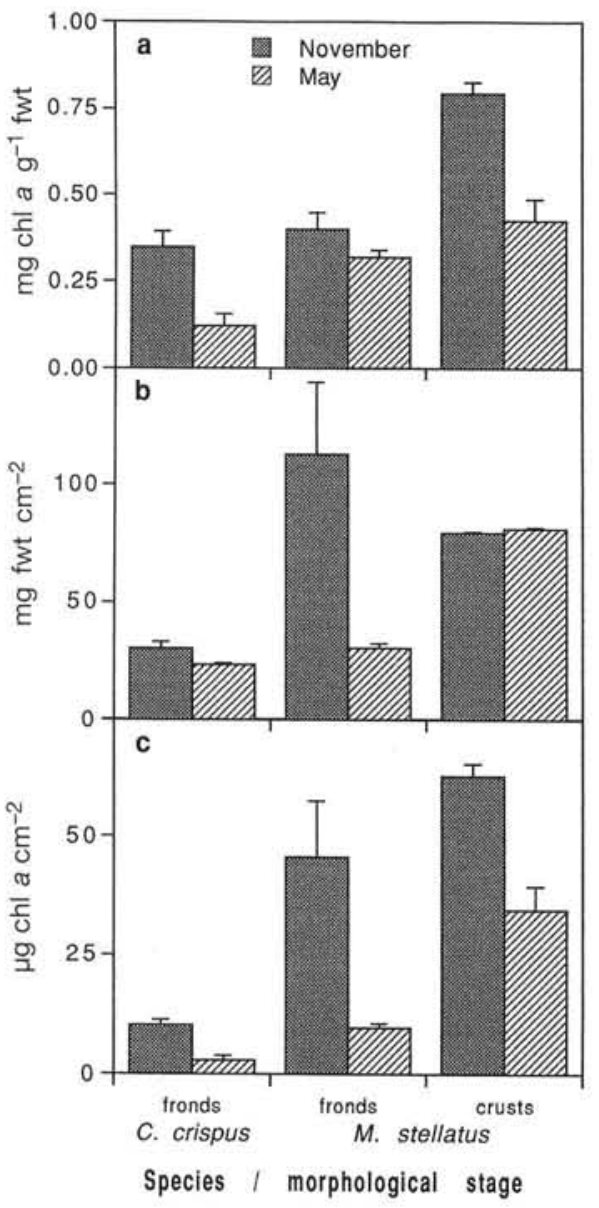

Fig. 3. Chondrus crispus and Mastocarpus stellatus. Relationships of chl $a$, biomass, and thallus surface area in November and May. (a) Concentration of chl a, (b) biomass per unit thallus area, and (c) chl a per unit thallus area. fwt: fresh weight. Means + SE, $n=5$

stellatus (Fig. 3a). Crusts of M. stellatus exhibited the greatest concentration of chl a g ${ }^{-1}$ biomass in both seasons $\left(F_{2.24}=39.32, \mathrm{p}<0.01\right)$.

In contrast to the seasonal variation of $\mathrm{chl} \mathrm{a} \mathrm{g}^{-1}$ fresh wt, little seasonal variation in biomass per unit projected surface area was observed in Chondrus crispus and crusts of Mastocarpus stellatus (Fig. 3b). However, fronds of $M$. stellatus exhibited significantly more biomass per unit projected area in the fall than the spring $\left(F_{1,24}=7.83, \mathrm{p}=0.01\right)$. Fronds of $M$. stellatus collected in the spring exhibited similar values of biomass per unit surface area to those of $C$. crispus.

The seasonal changes either in chl a per biomass, or biomass per unit area in both species consequently affected seasonal variation in the amount of chl a per unit projected surface area of thallus (Fig. 3c). The concentration of chl a per unit projected area was greater in fall thalli than in spring thalli of both species (non- parametric ANOVA, Zar 1984; $H=7.16, \mathrm{p}<0.01$ ). In both fall and spring, crusts of Mastocarpus stellatus had the most chl a per unit area and fronds of Chondrus crispus the least $(H=16.00, \mathrm{p}<0.01)$.

\section{Thermal acclimation}

Growth temperature affected the ability of Chondrus crispus to withstand high temperatures. Thalli grown at $15^{\circ} \mathrm{C}$ had positive rates of net photosynthesis at $35^{\circ} \mathrm{C}$, whereas thalli grown at $5^{\circ} \mathrm{C}$ did not (Fig. 4a). No differences in $P_{\max }$ between thalli acclimated at 5 and $15^{\circ} \mathrm{C}$ were observed at temperatures $\leq 30^{\circ} \mathrm{C}$.

Thermal acclimation of photosynthesis in Mastocarpus stellatus was observed in crusts, but not in fronds (Fig. 4b, c). Photosynthetic rates of fronds of M. stellatus grown at 5 and $15^{\circ} \mathrm{C}$ were not different from each other at temperatures from 5 to $35^{\circ} \mathrm{C}$. Although the

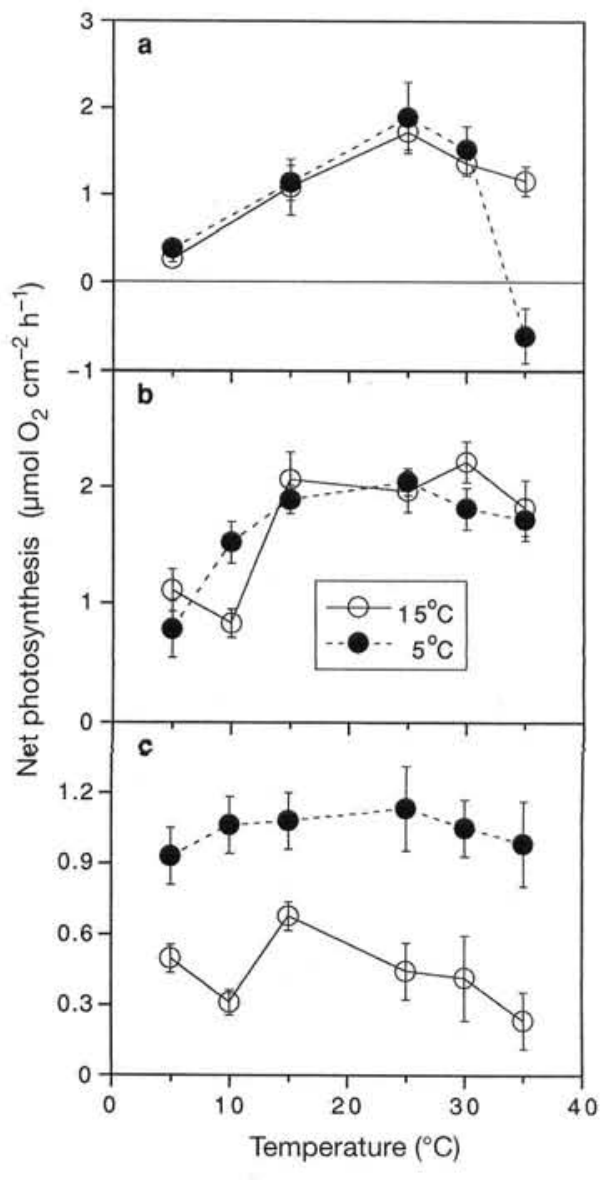

Fig. 4. Chondrus crispus and Mastocarpus stellatus. Effect of temperature on photosynthesis of algae grown at 5 and $15^{\circ} \mathrm{C}$. (a) C. crispus, (b) fronds of M. stellatus, (c) crusts of $M$. stellatus. Means $\pm \mathrm{SE}, \mathrm{n}=5$ 


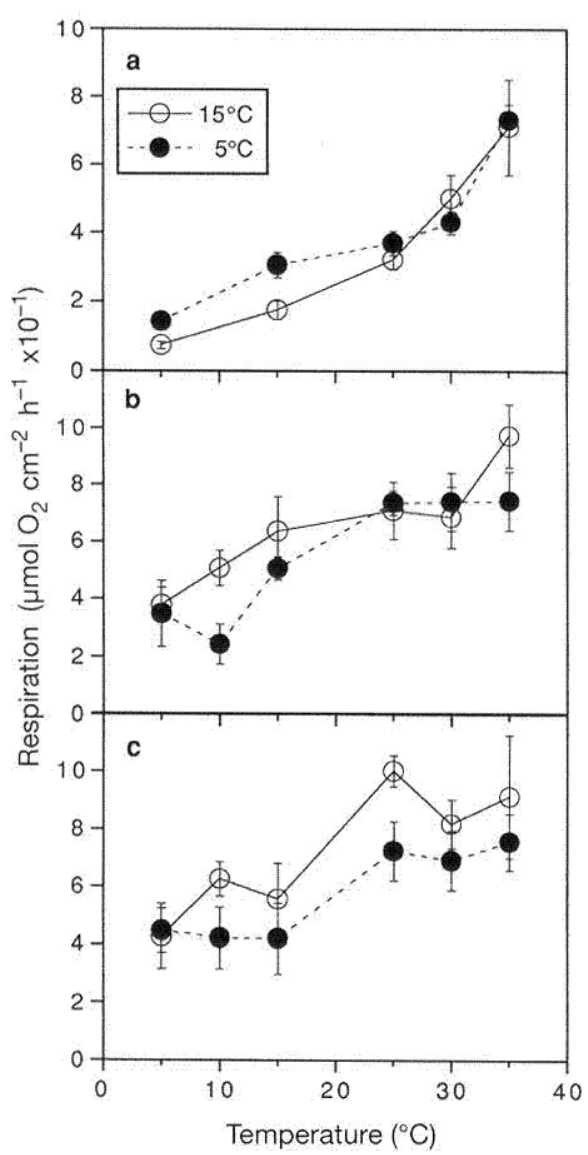

Fig. 5. Chondrus crispus and Mastocarpus stellatus. Effect of temperature on respiration of algae grown at 5 and $15^{\circ} \mathrm{C}$. (a) C. crispus, (b) fronds of $M$. stellatus, (c) crusts of $M$. stellatus. Means $\pm \mathrm{SE}, \mathrm{n}=5$

responses of photosynthesis to temperature for crusts grown at 5 and $15^{\circ} \mathrm{C}$ were similar, $5^{\circ} \mathrm{C}$ crusts exhibited higher photosynthetic rates at all temperatures, indicating acclimation of $P_{\max }$.

Chondrus crispus grown at $5^{\circ} \mathrm{C}$ exhibited slightly higher rates of respiration below $15^{\circ} \mathrm{C}$ than thalli grown at $15^{\circ} \mathrm{C}$, but no difference was observed at temperatures $\geq 25^{\circ} \mathrm{C}$ (Fig. 5a). Both life history phases of Mastocarpus stellatus showed similar patterns of increased respiration with increasing measurement temperature in thalli grown at 5 and $15^{\circ} \mathrm{C}$ indicating that no thermal acclimation occurred (Fig. 5b, c).

\section{Effects of desiccation and temperature}

Temperature affected the rate of desiccation, with fronds exposed to $30^{\circ} \mathrm{C}$ reaching $60 \%$ desiccation more rapidly $(1.2 \mathrm{~h}$ for both Chondrus crispus and Mastocarpus stellatus) than fronds exposed to $20^{\circ} \mathrm{C}$ $(1.9 \mathrm{~h}$ for each). Crusts dehydrated much more slowly than fronds at both $20^{\circ}$ ( $7.5 \mathrm{~h}$ to reach $60 \%$ desiccation $)$ and $30^{\circ} \mathrm{C}(5.2 \mathrm{~h})$.

Photosynthetic rates immediately after re-immersion following $60 \%$ desiccation at $20^{\circ} \mathrm{C}$ were reduced by one-third in fronds of Mastocarpus stellatus, and by two-thirds in Chondrus crispus, and crusts of M. stellatus, respectively (Fig. 6a). All 3 groups recovered photosynthesis at similar rates following $60 \%$ desiccation at $20^{\circ} \mathrm{C}$. However, full recovery of photosynthesis took longer in C. crispus $(24 \mathrm{~h})$ and crusts of $M$. stellatus $(6 \mathrm{~h})$ than in fronds of $M$. stellatus $(2 \mathrm{~h})$ because photosynthesis was initially reduced more.

The initial reduction of photosynthesis was greater following desiccation at $30^{\circ} \mathrm{C}$ than at $20^{\circ} \mathrm{C}$ in Chondrus crispus which exhibited no net photosynthesis immediately upon re-immersion in seawater (Fig. 6b). In contrast, reductions of photosynthesis of crusts and fronds of Mastocarpus stellatus at $30^{\circ} \mathrm{C}$ was similar to their respective reductions at $20^{\circ} \mathrm{C}$. All 3 groups rapidly recovered some photosynthesis within $2 \mathrm{~h}$ following rehydration. Whereas both phases of $M$. stellatus exhibited photosynthetic rates similar to control levels within 2 to $6 \mathrm{~h}$ following rehydration, photosynthesis of C. crispus was only $59 \%$ of control levels after $24 \mathrm{~h}$.

Desiccation at both 20 and $30^{\circ} \mathrm{C}$ increased respiration of fronds, but had variable effects on crusts (Fig. 7). Desiccation at $30^{\circ} \mathrm{C}$ increased respiration more in Chondrus crispus than in Mastocarpus stellatus, whereas a similar increase in respiration was observed following dehydration at $20^{\circ} \mathrm{C}$.

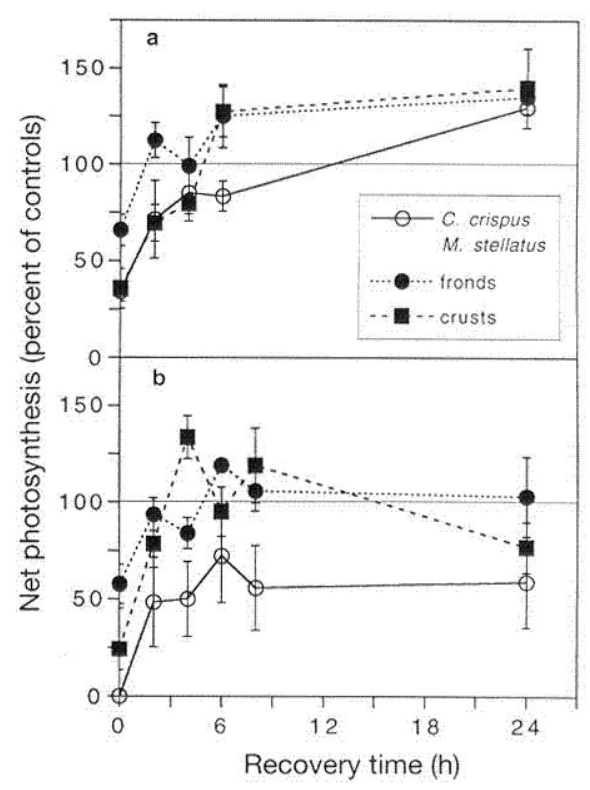

Fig. 6. Chondrus crispus and Mastocarpus stellatus. Recovery of photosynthesis following $60 \%$ thallus dehydration at (a) $20^{\circ} \mathrm{C}$ and (b) $30^{\circ} \mathrm{C}$. Means $\pm \mathrm{SE}, \mathrm{n}=5$, expressed as a percentage of control photosynthesis 


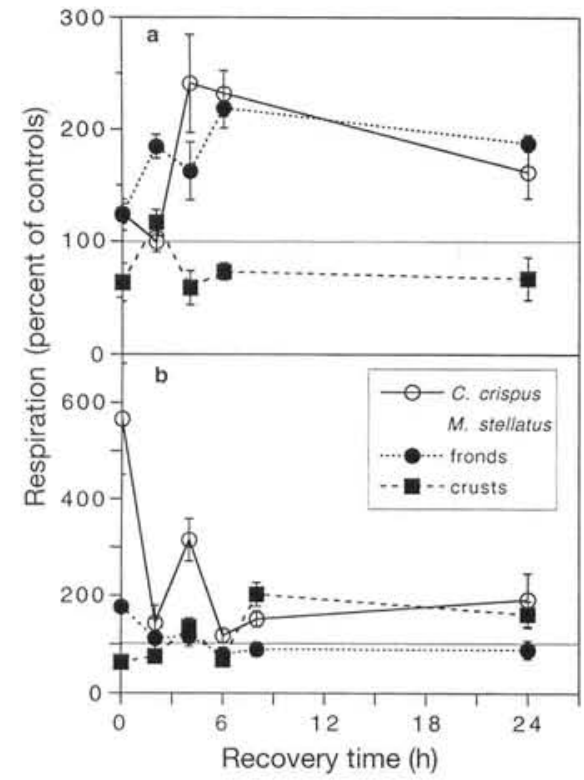

Fig. 7. Chondrus crispus and Mastocarpus stellatus, Recovery of respiration following $60 \%$ thallus dehydration at (a) $20^{\circ} \mathrm{C}$ and (b) $30^{\circ} \mathrm{C}$. Note difference in $y$-axis scale between (a) and (b). Means $\pm \mathrm{SE}, \mathrm{n}=5$, expressed as a percentage of control respiration

The changes in $P_{\max }$ due to desiccation are not corrected for dark respiration (i.e. they are rates of net photosynthesis). Our justification for using net, rather than gross, photosynthesis is that we have no evidence that rates of dark respiration are sustained at high light levels. Reductions in net photosynthesis could result from increases in respiration, rather than direct inhibition of photosynthesis. However, irrespective of the mechanism involved, the ecological significance of the reduction in $\mathrm{P}_{\max }$ is clear; it represents an impairment in the ability of an alga to achieve net carbon fixation and, hence, growth.

\section{Short-term recovery from freezing}

Photosynthesis in the 3 groups of macroalgae was affected differently by freezing for $6 \mathrm{~h}$ at $-20^{\circ} \mathrm{C}$ (Fig. 8a). Chondrus crispus exhibited no net photosynthesis immediately after re-immersion. Photosynthesis of crusts of Mastocarpus stellatus was reduced to $43 \%$ of unfrozen controls, whereas photosynthesis of fronds of $M$. stellatus was unaffected. Crusts fully recovered control photosynthetic rates within $24 \mathrm{~h}$ after freezing. In contrast, photosynthetic recovery of $C$. crispus was slow and incomplete with full recovery not occurring after $24 \mathrm{~h}$.

Freezing reduced respiration rate in Mastocarpus stellatus (Fig. 8b). Respiratiory rates of fronds of $M$. stellatus returned to control levels more rapidly than

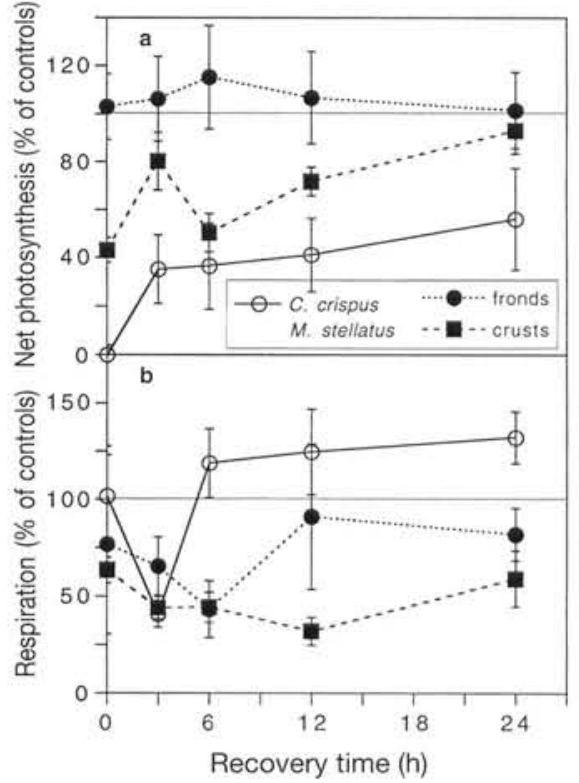

Fig. 8. Chondrus crispus and Mastocarpus stellatus. Recovery of (a) photosynthesis and (b) respiration following $6 \mathrm{~h}$ at $-20^{\circ} \mathrm{C}$. Means $\pm \mathrm{SE}, \mathrm{n}=5$, expressed as a percentage of control photosynthesis and respiration

crusts. Respiration rates of Chrondus crispus fluctuated above and below that of controls within $24 \mathrm{~h}$ following freezing.

\section{In situ growth rate}

Fronds of Chondrus crispus grew significantly faster than fronds of Mastocarpus stellatus $(t=6.39, \mathrm{df}=26$, $\mathrm{p}<0.01$ ). Growth of $C$. crispus was 2.65 ( $\pm 0.17 \mathrm{SE}$ ) g dry wt $\mathrm{m}^{-2} \mathrm{~d}^{-1}$ compared to 1.04 ( $\left.\pm 0.19 \mathrm{SE}\right) \mathrm{g}$ dry wt $\mathrm{m}^{-2} \mathrm{~d}^{-1}$ for $M$. stellatus. No measurable areal growth of crusts of $M$. stellatus was observed following $1 \mathrm{yr}$.

\section{DISCUSSION}

The diversity of adaptations allowing organisms to survive in the marine intertidal zone has long been appreciated. Our results show that the differences in physiological response to environmental conditions are as great among closely related, and anatomically and morphologically similar thalli (i.e. fronds of Chrondus crispus and Mastocarpus stellatus), as among morphologically distinct thalli (i.e. between crusts and fronds). Moreover, the relative physiological responses of fronds and crusts varies with the environmental variable considered. Consequently, functional morphology models (Littler \& Littler 1980) are of limited value for understanding the comparative physiological 
ecology of C. crispus and M. stellatus. More generally, these results suggest that among macroalgae physiological constraints (e.g. degree of tissue differentiation, translocation, allocation of metabolic energy to growth, reproduction, tolerance) determine the extent to which life history characteristics and morphology are linked.

The intraspecific differences in stress tolerance we observed among heteromorphic phases of Mastocarpus stellatus (discussed below) are consistent with their zonation in natural populations. Whereas many previous studies of heteromorphic algae have focused primarily on morphological trade-offs associated with biotic variables, such as herbivore susceptibility versus rapid growth rate (Littler \& Littler 1980, Lubchenco \& Cubit 1980, Slocum 1980, Steneck 1986, Steneck \& Dethier 1994), our data suggest that the physiological characteristics among different phases of heteromorphic algae are determinants of their distribution and abundance, and life history traits. We confirm the results of previous studies that found differences in stress tolerance among the morphologically similar fronds of Chondrus crispus and $M$. stellatus that are consistent with their respective distributions (Mathieson \& Burns 1971, Dudgeon et al. 1989, 1990).

\section{Comparing stress tolerance among heteromorphic phases of Mastocarpus stellatus}

A comparison of metabolic responses to desiccation and freezing between morphological phases of Mastocarpus stellatus reveals that crusts exhibited lower tolerances to these factors. The greater tolerance to desiccation and freezing of fronds of $M$. stellatus suggests that these characteristics enhance the survival of fronds that largely occur higher on the shore and experience more frequent and prolonged exposure to these stresses compared to crusts growing lower on the shore. The differences reported here are in response to a single episode of freezing or desiccation, whereas in nature these algae are repeatedly exposed to these stresses. However, this type of experiment is a good predictor of the relative ability of macroalgae to survive and grow when subject to natural daily stress (Dudgeon et al. 1989, 1990).

The phase-specific physiological differences between morphs of Mastocarpus stellatus can be explained by at least 3 hypotheses. The first 2 hypotheses require that fronds and crusts of $M$. stellatus at the study site be genetically isolated, which is supported by the fact that all cystocarpic fronds of $M$. stellatus cultured from our study sites over a $2 \mathrm{yr}$ period $(>200)$ were apomictic (Dudgeon unpubl.). Carpospores from apomictic fronds germinate directly into new apomictic fronds, rather than the crustose tetrasporophytes that develop from carpospores of sexual gametophytes (Maggs 1988). The large size and slow growth rate of crusts of Mastocarpus sp. (Paine et al. 1979) suggests that they are long-lived, and that sexual gametophytes need be produced infrequently to sustain the abundance of crusts. In the case of genetic isolation, differences between phases resulted either from (1) adaptation of fronds in response to selection for stress tolerance higher on the shore, or (2) secondary loss of stress tolerant characteristics in crusts.

An alternative hypothesis is that sexual gametophytes are present, and crusts and fronds share a common gene pool, with the physiological differences resulting from differential gene expression associated with an environmental trigger. The crusts of Mastocarpus stellatus were growing beneath a dense canopy of Chondrus crispus, which probably ameliorated environmental fluctuations (Brawley \& Johnson 1991, Pearson \& Davison 1993), and the differences may reflect phenotypic acclimation to the greater stress experienced by canopy-forming fronds. However, 2 lines of evidence are inconsistent with this hypothesis. First, fronds of M. stellatus do not appear to acclimate, rather they exhibit a uniformly high stress tolerance regardless of culture conditions (Dudgeon et al. 1990). Second, if crusts were capable of expressing a similar degree of stress tolerance to that of fronds, we would expect the upper distribution limits of both morphological phases to be similar. We do not know if the physiological differences observed among fronds occur in both apomictic thalli and sexual gametophytes. The proportion of apomictic fronds on a biogeographic scale increases at higher latitudes in at least 2 species of the genus Mastocarpus (Guiry \& West 1983, Zupan \& West 1988) and in other red algae (Rueness 1968, DeCew \& West 1981, DeCew et al. 1981), suggesting that physiological differences between apomictic and sexual fronds exist. However, Zupan \& West (1990) observed few differences in metabolic responses to light and temperature between northern (presumably apomictic) and southern (presumably sexual) gametophyte populations of $M$. papillatus.

\section{Comparative physiology in relation to morphology}

There was no obvious correlation between thallus morphology and either the photosynthesis-irradiance parameters, metabolic responses to thermal variation, or tolerance to desiccation or freezing (Table 1). Indeed, in this respect, fronds of Chrondus crispus and crusts of Mastocarpus stellatus, which are morphologically different and genetically isolated are no more dissimilar than are morphologically similar thalli (i.e. 
fronds of C. crispus and M. stellatus), or the alternate phases of M. stellatus. Our results indicate that both desiccation and freezing reduce net photosynthetic rate to a similar extent in C. crispus and crusts of $M$. stellatus. However, photosynthesis of crusts of M. stellatus apparently is more resilient because it recovers more rapidly following exposure to either stress. Damage to the photosynthetic and respiratory metabolisms of $C$. crispus caused by desiccation and freezing is consistent with previous findings (Mathieson \& Burns 1971, Davison et al. 1989, Dudgeon et al. 1989, 1990). In addition to determining the desiccation and freezing tolerances of crusts of $M$. stellatus relative to fronds of $M$. stellatus and C. crispus, our results also support previous studies showing that fronds of $M$. stellatus exhibit the greatest tolerance to these factors. The physiological damage to $C$. crispus thalli caused by desiccation is temperature dependent with greater fluctuations in metabolic rates occurring at warmer temperatures. Previous laboratory and field studies have found similar temperature dependent effects of desiccation on metabolic rates of seaweeds (Brinkhuis et al. 1976, Schonbeck \& Norton 1978, Madsen \& Maberly 1990, Bell 1993, Britting \& Chapman 1993) and Pearson \& Davison (1993) observed that the rate of freezing determined the physiological response of intertidal fucoids. Interestingly, metabolic stress on fronds and crusts of $M$. stellatus was not exacerbated at the higher temperature in this study in spite of the fact that warmer thalli desiccated more rapidly.

\section{Seasonal variation in light use}

Light-use characteristics of fronds of Chondrus crispus and fronds and crusts of Mastocarpus stellatus in fall and spring show a slight relationship with thallus morphology. The only factor that supported predictions of the form-function hypothesis was the rate of maximum net photosynthesis. The area-specific $P_{\max }$ of fronds of C. crispus and M. stellatus measured at $10^{\circ} \mathrm{C}$ were similar in fall and spring, and greater than that of crusts of $M$. stellatus. $P_{\max }$ of fronds varied seasonally, with greater rates occurring during fall. In contrast, $P_{\max }$ of crusts did not vary seasonally. A thick crustose morphology, such as that of $M$. stellatus tetrasporophytes, may contribute to lower rates of $P_{\max }$ compared to fronds because a smaller proportion of cells are photosynthetic due to the thicker thallus $(\sim 750$ to $1000 \mu \mathrm{m}$; Dudgeon unpubl.).

The same seasonal trends of saturation PPFD $\left(I_{k}\right)$ and compensation PPFD $\left(I_{c}\right)$ occurred in both crusts and fronds. Overall, crusts exhibited lower, and more variable, $I_{\mathrm{k}}$ values and a higher $I_{\mathrm{c}}$ of photosynthesis in spring and fall. The higher $I_{c}$ of crusts of Mastocarpus stellatus indicates that less net primary production, rel-

Table 1. Chondrus crispus and Mastocarpus stellatus. Summary of physiological and ecological life history characteristics of fronds of both species and crusts of $M$. stellatus obtained from this and other studies. Assessment represents rank relative to the other 2 thallus groups for each trait

\begin{tabular}{|c|c|c|c|c|}
\hline \multirow[t]{2}{*}{ Trait } & \multicolumn{3}{|c|}{ Species/morphology } & \multirow[t]{2}{*}{ Source } \\
\hline & $\begin{array}{l}\text { C. crispus } \\
\text { fronds }\end{array}$ & $\begin{array}{l}\text { M. stellatus } \\
\text { fronds }\end{array}$ & $\begin{array}{l}\text { M. stellatus } \\
\text { crusts }\end{array}$ & \\
\hline Intertidal zone habitat & Low & Mid & Low & Dudgeon (1992) \\
\hline \multicolumn{5}{|l|}{ Light-use characteristics } \\
\hline$P_{\max }$ & High & High & Low & This study \\
\hline$\alpha$ & Moderate & Moderate & Moderate & This study \\
\hline$I_{\mathrm{c}}$ & Low & Moderate & High & This study \\
\hline Seasonal acclimation & Yes & Yes & Yes & This study \\
\hline Thermal acclimation & Yes & No & Yes & This study \\
\hline \multicolumn{5}{|c|}{ Stress tolerance characteristics (desiccation and freezing) } \\
\hline Net photosynthetic rate & Low & High & Moderate & This study \\
\hline Recovery of net photosynthetic rate & Slow & Rapid & Rapid & This study \\
\hline Growth rate in situ & Rapid & Moderate & Slow & Paine et al. (1979), this study \\
\hline Competitive ability & Strong & Weak & $?^{\mathrm{a}}$ & Dudgeon (1992) \\
\hline Thallus longevity & Short & Short & Very long & $\begin{array}{l}\text { Paine et al. (1979), Dudgeon \& } \\
\text { Johnson (1992), Steneck \& Dethier (1994) }\end{array}$ \\
\hline Herbivore susceptibility & Low & Low & Very low & $\begin{array}{l}\text { Slocum (1980), Lubchenco (1978), } \\
\text { Dudgeon (1992) }\end{array}$ \\
\hline
\end{tabular}


ative to fronds, occurs at very low light levels, a condition that may be common for sub-canopy crustose algae. The higher $I_{c}$ of crusts of $M$. stellatus resulted from greater respiratory rates per unit thallus area that is attributable, in part, to a high biomass to photosynthetic surface area ratio. Interestingly, crusts do not show lower rates of respiration or greater light harvesting efficiency, characteristics typically expected among shade plants. Indeed, light use characteristics of crusts of $M$. stellatus in certain respects are seemingly non-adaptive. The slow growth of crusts of Mastocarpus sp. (Paine et al. 1979, this study) may be reflected in the fact that these thalli require more light than fronds to achieve net carbon fixation and have lower maximum rates of photosynthesis.

Both crusts and fronds showed increased light harvesting efficiency $(\alpha)$, reduced $I_{\mathrm{c}}$ and $I_{\mathrm{k}}$ during the fall. Light harvesting efficiency was not different between species, nor between crusts and fronds of Mastocarpus stellatus, when compared within a season. Acclimation of $\alpha$ to variation in temperature and light intensity has been observed in numerous micro- and macroalgae, and in higher plants (Smith et al. 1983, Anderson \& Osmond 1987, Baker \& McKiernan 1988, Gerard 1988, Henley \& Ramus 1989, Davison 1991, Falkowski \& LaRoche 1991, Kübler 1992). Since several factors covary seasonally with light intensity, such as temperature and nutrient concentrations, we cannot ascribe these seasonal changes as solely due to photoacclimation to the lower light levels in November than May.

The changes observed in characteristics of light use were associated with increased concentrations of chl a per unit thallus area. The increase in chl a per unit thallus area was a consequence of increased chl a per unit biomass in fronds of Chondrus crispus and crusts of Mastocarpus stellatus, but not in fronds of M. stellatus. The increase in chl $a$ and $\alpha$ in C. crispus and crusts of $M$. stellatus presumably reflected an increase in either the size or density of photosynthetic units per cell. In contrast, chl a per unit area of fronds of M. stellatus increased in fall solely because the biomass per unit projected area of thallus was greater in the fall. Thus, the increase in light harvesting efficiency of fronds of $M$. stellatus during fall may be due to the change in morphology (that increased the number of photosynthetic units per unit projected area by virtue of a greater quantity of cells per unit projected area), rather than changes in pigment content per cell. The morphological change of fronds of $M$. stellatus was associated with the development of reproductive papillae in the fall (Burns \& Mathieson 1972, Dudgeon pers. obs). The presence of papillae increases the photosynthetic area per unit projected thallus area causing an increase in $P_{\max }$ and $\alpha$ without necessarily indicating photoacclimation at the cellular level.

\section{Responses to temperature}

The responses of $P_{\max }$ to temperature were more similar between fronds of the 2 species than between fronds and crusts. The $P_{\max }$ of crusts was insensitive to instantaneous thermal variation, whereas the $P_{\max }$ of fronds was sensitive to thermal variation when grown at either 5 or $15^{\circ} \mathrm{C}$. A similar pattern of photosynthetic responses to temperature was also observed between morphologically distinct life history phases of Mastocarpus papillatus (Zupan \& West 1990).

Despite similar responses of $P_{\max }$ to instantaneous changes in temperature among fronds of the 2 species, the degree of thermal acclimation differed. Photosynthesis of Chondrus crispus exhibited a thermal acclimation response involving increased tolerance to high thermal extremes, such that fronds grown at $15^{\circ} \mathrm{C}$ could maintain net photosynthesis at $35^{\circ} \mathrm{C}$, whereas fronds grown at $5^{\circ} \mathrm{C}$ could not. Acclimation of photosynthesis to environmental extremes appears characteristic of $C$. crispus. Fronds acclimated to warmer temperatures (e.g. $\left.20^{\circ} \mathrm{C}\right)$ can maintain higher rates of photosynthesis than cold-acclimated fronds (e.g. $5^{\circ} \mathrm{C}$ ) over several hours exposure to $30^{\circ} \mathrm{C}_{i}$ a condition that may occur during low tides during summer (Kübler \& Davison 1993). Similarly, photosynthesis of cold-acclimated fronds, especially those that experience daily mild freezing events, exhibit greater tolerance than warm-acclimated fronds to freezing temperatures that occur during winter in the Gulf of Maine (Dudgeon et al. 1990). Thermal acclimation of light-limited photosynthesis also occurs in C. crispus enabling greater photosynthetic competence at low light in warm-acclimated fronds (Kübler 1992).

Crusts of Mastocarpus stellatus also exhibited thermal acclimation of photosynthesis. The acclimation response involved increased $P_{\max }$ at all assay temperatures in $5^{\circ} \mathrm{C}$ acclimated crusts relative to those acclimated at $15^{\circ} \mathrm{C}$, rather than increased tolerance to thermal extremes as observed in Chondrus crispus. Because crusts of $M$. stellatus grow slowly, thermal acclimation of $P_{\max }$ at low temperatures may enable some growth during winter when the canopy of $C$. crispus is thinned (Dudgeon \& Johnson 1992). Alternatively, the increase in $P_{\max }$ of cold-acclimated thalli may compensate, in part, for the energetic cost of tetraspore development. Tetrasporogenesis in crusts of M. stellatus is stimulated by short-day conditions (Guiry \& West 1983) that temporally coincide with decreasing seawater temperatures. Acclimation of $\mathrm{P}_{\max }$ to cold temperatures has also been observed in Laminaria sp. that also occur in the low intertidal and subtidal zones of sub-arctic shores (Davison 1987).

In contrast to Chondrus crispus and the alternate stage crusts, no acclimation of photosynthesis to tem- 
perature was observed in fronds of Mastocarpus stellatus. Similar photosynthetic rates of 5 and $15^{\circ} \mathrm{C}$ grown fronds suggests that photosynthetic phenomena over the temperature range examined are genetically determined without environmental influence. Evidence from previous studies also supports the hypothesis that fronds of $M$. stellatus are well suited for photosynthesis, growth and survival over a wide temperature range without having to acclimate (Mathieson \& Burns 1971, Dudgeon et al. 1989, 1990).

\section{Comparative life history characteristics}

Studies of life history characteristics among macroalgae have focused on the trade-offs associated with morphological attributes (e.g. crustose frondose morphologies; Paine et al. 1979, Littler \& Littler 1980, Lubchenco \& Cubit 1980, Slocum 1980, Dethier 1981, Littler \& Arnold 1982, Steneck \& Watling 1982, Zupan \& West 1990, Steneck \& Dethier 1994). As in previous studies, we found physiological differences among heteromorphic algae. However, we observed physiological differences to be as great, or greater, among morphologically similar thalli as among morphologically distinct thalli. Thus, there was no clear relationship between algal morphology and physiological responses to environmental variation with respect to Chondrus crispus and Mastocarpus stellatus.

Despite the lack of a relationship between physiological performance and algal morphology, there is evidence of trade-offs between different ecological traits (Table 1). For instance, morphologically similar fronds of Chondrus crispus and Mastocarpus stellatus exhibit similar rates of light saturated photosynthesis. However, C. crispus grows more rapidly and is a dominant competitor among littoral algae (Lubchenco 1980, Dudgeon 1992), but is intolerant of physiological and mechanical stress relative to $M$. stellatus (Dudgeon et al. 1989, 1990, Dudgeon \& Johnson 1992, this study). Crusts of $M$. stellatus resist herbivory and are very long-lived, and may compete effectively by virtue of their persistence, but exhibit low rates of productivity, very slow growth and a moderate level of tolerance to physiological stress. These combinations of characteristics of C. crispus, and fronds and crusts of M. stellatus, suggest that there are metabolic trade-offs that shape the life history characteristics of these 2 species.

The concept of trade-offs is central to studies involving life history theory. Trade-offs of life history characteristics, such as those depicted in Table 1, may result because energy allocated to one metabolic process is not available for another (Levins 1968). Evidence consistent with this axiom is observed in negative correlations between, for example, reproductive output and growth, or reproductive output and survival in many plant and animal species (Harper 1977, Stearns 1992). A significant aspect of this study is the suggestion that the trade-offs of life history characteristics among these 2 representative rhodophyte species are not causally linked with thallus morphology. Whereas among many plant and animal taxa of considerable anatomical complexity, physiological constraints may codetermine life history and morphology (Blackstone \& Buss 1992, 1993, S. R. Dudgeon \& L. W. Buss unpubl.), the lesser degree of tissue differentiation among rhodophyte algae uncouples this link. Life history traits may be determined at the cellular level by differential allocation of metabolic energy among physiological processes associated with stress tolerance and processes associated with rapid growth independent of thallus morphology, as exemplified by these closely related species.

Acknowledgements. S.R.D. thanks N. Blackstone and L. W. Buss for many illuminating discussions about life history evolution. We acknowledge the comments of 3 anonymous reviewers that improved the quality of this manuscript. This research was supported by National Science Foundation grant OCE 9012622 to I.R.D., Maine Agricultural Experiment Station funds to R.L.V. and University of Maine Center for Marine Studies Research Assistantships to S.R.D. and J.E.K.

\section{LITERATURE CITED}

Anderson, J. M., Osmond, C. B. (1987). Shade-sun responses: compromises between acclimation and photoinhibition. In: Kyle, D. J., Osmond, C. B., Arntzen, C. J. (eds.) Photoinhibition. Elsevier, Amsterdam, p. 1-38

Baker, N. R., McKiernan, M. (1988). Modifications to the photosynthetic apparatus of higher plants in response to changes in the light environment. Biol. J. Linn. Soc. 34: 193-203

Bell, E. C. (1993). Photosynthetic response to temperature and desiccation of the intertidal alga Mastocarpus papillatus. Mar. Biol. 117: 337-346

Bidwell, R. G. S., McLachlan, J. (1985). Carbon nutrition of seaweeds: photosynthesis, photorespiration and respiration. J. exp. mar. Biol. Ecol. 86: 15-46

Blackstone, N. W., Buss, L. W. (1992). Treatment with 2,4dinitrophenol mimics ontogenetic and phylogenetic changes in a hydractiniid hydroid. Proc. Natl Acad. Sci. U.S.A. 89: $4057-4061$

Blackstone, N. W., Buss, L. W. (1993). Experimental heterochrony in hydractiniid hydroids: why mechanisms matter. J. evol. Biol. 6: 307-327

Brawley, S. H., Johnson, L. E. (1991). Survival of fucoid embryos in the intertidal zone depends upon developmental stage and microhabitat. J. Phycol. 27: 179-186

Brinkhuis B. H., Tempel, R. N., Jones, R. F. (1976). Photosynthesis and respiration of exposed salt-marsh fucoids. Mar. Biol. 34: 349-359

Britting, S. A., Chapman, D. J. (1993). Physiological comparison of the isomorphic life history phases of the high intertidal alga Endocladia muricata (Rhodophyta). J. Phycol. 29: 739-745 
Burns, R. L., Mathieson, A. C. (1972). Ecological studies of economic red algae. III. Growth and reproduction of natural and harvested populations of Gigartina stellata (Stackhouse) Batters in New Hampshire. J. exp. mar. Biol. Ecol. 9: 77-95

Chopin, T., Floch, J. Y. (1992). Eco-physiological and biochemical study of two of the most contrasting forms of Chondrus crispus (Rhodophyta: Gigartinales). Mar. Ecol. Prog. Ser. 81: 185-195

Connell, J. H. (1972) Community interactions on marine rocky intertidal shores. A. Rev. Ecol. Syst. 4: 169-192

Davison, I. R. (1987). Adaptation of photosynthesis in Laminaria saccharina (Phaeophyta) to changes in growth temperature. J. Phycol. 23: 273-283

Davison, I. R. (1991). Environmental effects on algal photosynthesis: temperature. J. Phycol. 27: 2-8

Davison, I. R., Dudgeon, S. R., Ruan, H-M. (1989). The effect of freezing on seaweed photosynthesis. Mar. Ecol. Prog. Ser. 58: 123-131

DeCew, T.C., West, J. A. (1981). Life histories in the Phyllophoraceae (Rhodophyta: Gigartinales) from the Pacific coast of North America. I. Gymnogrongus linearis and $G$. leptophyllus. J. Phycol. 17: 240-250

DeCew, T. C., West, J. A., Ganesan, E. K. (1981). The life histories and developmental morphology of two species of Gloiosiphonia (Rhodophyta: Cryptonemiales, Gloiosiphonaceae) from the Pacific coast of North America. Phycologia 20: 415-423

Dethier, M. N. (1981). Heteromorphic algal life histories: the seasonal pattern and response to herbivory of the brown crust, Ralfsia californica. Oecologia 49: 333-339

Dethier, M. N. (1994). The ecology of intertidal algal crusts: variation within a functional group. J. exp. mar. Biol. Ecol. 177: $37-71$

Dring, M. J., Brown, F. A. (1982). Photosynthesis of intertidal brown algae during and after periods of emersion: a renewed search for physiological causes of zonation. Mar. Ecol. Prog. Ser, 8: 301-308

Dudgeon, S. R. (1992). Factors mediating competition between Chondrus crispus and Mastocarpus stellatus (Rhodophyta). Ph.D. dissertation, University of Maine, Orono

Dudgeon, S. R., Davison, I. R., Vadas, R. L. (1989). Effect of freezing on photosynthesis in intertidal macroalgae: relative tolerances of Chondrus crispus and Mastocarpus stellatus (Rhodophyta). Mar. Biol. 101: 107-114

Dudgeon, S. R., Davison, I. R., Vadas, R. L. (1990). Freezing tolerance in the intertidal red algae Chondrus crispus and Mastocarpus stellatus: relative importance of acclimation and adaptation. Mar. Biol. 106: 427-436

Dudgeon, S. R., Johnson, A. S. (1992). Thick vs. thin: thallus morphology and tissue mechanics influence differential drag and dislodgement of two co-dominant seaweeds. J. exp. mar. Biol. Ecol. 165: 23-43

Duncan, M. J., Harrison, P. J. (1982). Comparisons of solvents for extracting chlorophylls from marine macrophytes. Botanica mar. 25: 445-447

Falkowski, P. G., LaRoche, J. (1991). Acclimation to spectral irradiance in algae. J. Phycol. 27: 8-14

Gerard, V. (1988). Ecotypic differentiation in light-related traits of the kelp Laminaria saccharina. Mar. Biol. 97: $25-36$

Green, J. E. (1983). Factors controlling the vertical zonation of two intertidal seaweeds: Chondrus crispus Stackhouse and Gigartina stellata (Stackhouse) Batters. M.Sc. thesis, Northeastern University, Boston

Guiry, M. D., West, J. A. (1983). Life history and hybridization studies on Gigartina stellata and Petrocelis cruenta (Rhodophyta) in the North Atlantic. J. Phycol. 19: 474-494

Hanisak, M. D., Littler, M. M., Littler, D. S. (1988). Significance of macroalgal polymorphism: intraspecific tests of the functional form model. Mar. Biol. 99: 157-165

Hannach, G, Santelices, B. (1985). Ecological differences between the isomorphic reproductive phases of two species of Iridaea (Rhodophyta: Gigartinales). Mar. Ecol. Prog. Ser. 22: 291-303

Harper, J. L. (1977). Population biology of plants. Academic Press, London

Henley, D., Ramus, J. (1989). Photoacclimation of Ulva rotundata (Chlorophyta) under natural irradiance. Mar. Biol. 103: $261-266$

Kübler, J. E. (1992). Temperature and photosynthesis in red algae. Ph.D. dissertation, University of Maine, Orono

Kübler, J. E., Davison, I. R. (1993). High-temperature tolerance of photosynthesis in the red alga, Chondrus crispus. Mar. Biol. 117: 327-336

Kuebler, J. E., Davison, I. R., Yarish, C. (1991). Photosynthetic adaptation to temperature in the red algae Lomentaria baileyana and Lomentaria orcadensis. Br. Phycol. J. 26: $9-19$

Levins, R. (1968). Evolution in changing environments. Princeton University Press, Princeton, NJ

Littler, M. M., Arnold, K. E. (1982). Primary productivity of marine macroalgal functional-form groups from southwestern North America. J. Phycol. 18: 307-311.

Littler, M. M., Littler, D. S. (1980). The evolution of thallus form and survival strategies in benthic marine macroalgae: field and laboratory tests of a functional form model. Am. Nat. 116: 25-44

Lubchenco, J. (1978). Plant species diversity in a marine intertidal community: importance of herbivore food preference and algal competitive abilities. Am. Nat. 112: 23-39

Lubchenco, J. (1980). Algal zonation in the New England rocky intertidal community: an experimental analysis. Ecology 61: 333-344

Lubchenco, J. Cubit, J. (1980). Heteromorphic life histories of certain marine algae as adaptations to variations in herbivory. Ecology 61: 676-687

Lüning, K. L. (1990). Seaweeds: their environment, biogeography, and ecophysiology. Wiley \& Sons, New York

Madsen, T. V., Maberly, S. C. (1990). A comparison of air and water as environments for photosynthesis by the intertidal alga Fucus spiralis. J. Phycol, 26: 24-30.

Maggs, C. A. (1988). Intraspecific life history variability in the Florideophycidae (Rhodophtya). Botanica. mar. 31: $465-490$

Mathieson, A. C., Burns, R. L. (1971). Ecological studies of economic red algae. I. Photosynthesis and respiration of Chondrus crispus Stackhouse and Gigartina stellata (Stackh.) Batters. J. exp. mar. Biol. Ecol. 7: 197-206

Mathieson, A. C., Burns, R. L. (1975). Ecological studies of economic red algae. V. Growth and reproduction of natural and harvested populations of Chondrus crispus Stackhouse in New Hampshire. J. exp. mar. Biol. Ecol. 17: $137-156$

Mathieson, A. C., Norall, T. L. (1975). Physiological studies of subtidal red algae. J. exp. mar. Biol. Ecol. 17: 137-156

Oates, B. R. (1985). Photosynthesis and amelioration of desiccation in the intertidal saccate alga Colpomenia peregrina. Mar. Biol. 89: 109-119

Oates, B. R. (1986). Components of photosynthesis in the intertidal saccate alga Halosaccion americanum (Rhodophyta, Palmariales). J. Phycol. 22: 217-223

Paine, R. T., Slocum, C. J., Duggins, D. O. (1979). Growth and 
longevity in the crustose red alga Petrocelis middendorfii. Mar. Biol, 51: 185-192

Pearson, G. A., Davison, I. R. (1993). Freezing rate and duration determine the physiological response of intertidal fucoids to freezing. Mar. Biol. 115: 353-362

Prince, J. S., Kingsbury, J. M. (1973). The ecology of Chondrus crispus at Plymouth, Massachusetts. II. Field studies. Am. J. Bot. 60: 964-975

Provasoli, L. (1968). Media and prospects for the cultivation of marine algae. In: Watanabe, A., Hattori, A. (eds.). Cultures and collections of algae. Jap. Soc. Plant Physiol., Hakone, p. $63-75$

Rueness, J. (1968). Paraspores from Plumaria elegans (Bonnem.) Schmitz in culture. Norw. J. Bot. 15:220-224

Schonbeck, M. W., Norton, T. A. (1978). Factors controlling the upper limits of fucoid algae on the shore. J. exp. mar. Biol. Ecol. 31: 303-313

Slocum, C. J. (1980). Differential susceptibility to grazers in two phases of an intertidal alga: advantages of heteromorphic generations. J. exp. mar. Biol. Ecol. 46: 99-110

Smith, R. G., Wheeler, W. N., Srivastava, L. M. (1983). Seasonal photosynthetic performance of Macrocystis integrifolia (Phaeophyceae). J. Phycol. 19: 352-359

Smith, C. M., Berry, J. A. (1986). Recovery of photosynthesis after exposure of intertidal algae to osmotic and tempera-

This article was submitted to the editor ture stresses: comparative studies of species with differing distributional limits. Oecologia 70: 6-12

Stearns, S. C. (1992). The evolution of life histories. Oxford University Press, Oxford

Steneck, R. S. (1986). The ecology of coralline algal crusts: convergent patterns and adaptive strategies. A. Rev. Ecol. Syst. 17: 273-303

Steneck, R. S., Dethier, M. N. (1994). A functional group approach to the structure of algal-dominated communities. Oikos 69: 476-498

Steneck, R. S., Watling, L. (1982). Feeding capabilities and limitations of herbivorous molluscs: a functional group approach. Mar. Biol. 68: 299-319

West, J. A., Polanshek, A. R., Guiry, M. D. (1977). The life history in culture of Petrocelis cruenta J. Agardh (Rhodophyta) from Ireland. Br. Phycol. J. 12: 45-53

Zaneveld, J. (1969). Factors controlling the delimitation of littoral benthic marine algal zonation. Am. Zool. 9: 367-391

Zupan, J. R., West, J. A. (1988), Geographic variation in the life history of Mastocarpus papillatus (Rhodophyta). J. Phycol. 24: 223-229

Zupan, J. R., West, J. A. (1990). Photosynthetic responses to light and temperature of the heteromorphic marine alga Mastocarpus papillatus (Rhodophyta). J. Phycol. 26: 232-239

Manuscript first received: May 24, 1994

Revised version accepted: October 4, 1994 